\title{
Orenia salinaria sp. nov., a fermentative bacterium isolated from anaerobic sediments of Mediterranean salterns
}

\author{
Sophie Mouné, ${ }^{1,4}$ Claire Eatock, ${ }^{2}$ Robert Matheron, ${ }^{3}$ John C. Willison, ${ }^{4}$ \\ Agnès Hirschler, ${ }^{3}$ Rodney Herbert ${ }^{2}$ and Pierre Caumette ${ }^{1}$
}

\footnotetext{
1 Laboratoire d'Ecologie Moléculaire-Microbiologie, IBEAS, Université de Pau, 64000 Pau, France

2 Department of Biological Sciences, University of Dundee, Dundee DD1 4HN, UK

3 Microbiologie IMEP, Faculté des Sciences et Techniques St Jérôme 13397 Marseille, Cedex 20, France

${ }^{4}$ Laboratoire de Biochimie et Biophysique des Systèmes Intégrés, DBMS, CEA Grenoble, 38054 Grenoble, Cedex 9, France
}

\author{
Author for correspondence: Pierre Caumette. Tel: +33 5599231 46. Fax: +33 559808311. \\ e-mail: pierre.caumette@univ-pau.fr
}

\begin{abstract}
A diverse range of fermentative bacteria have been isolated from the commercial salterns of Salin-de-Giraud (Camargue, France). One of these isolates, strain SG $3902^{\top}$, has many of the morphological and physiological characteristics of the genus Orenia, as was confirmed by a phylogenetic study based on $16 \mathrm{~S}$ rRNA gene sequencing. The closest species is Orenia marismortui, with a similarity of only $95 \cdot 1 \%$. However, strain SG $3902^{\top}$, unlike $O$.

marismortui, does not ferment mannose, glycogen or starch. The G+C contents of the DNA also differ significantly, being $29.6 \mathrm{~mol} \%$ for 0 . marismortui and $33.7 \mathrm{~mol} \%$ for strain SG $3902^{\top}$. On the basis of these physiological and genetic differences, it is proposed that strain SG $3902^{\top}$ should be considered as a representative of a new species belonging to the genus Orenia, under the name Orenia salinaria sp. nov. The type strain is SG $3902^{\top}$ (= ATCC 700911).
\end{abstract}

Keywords: halophilic fermentative bacteria, salterns, Haloanaerobiales, hypersaline environments, Orenia

\section{INTRODUCTION}

Several halophilic, obligately anaerobic, fermentative bacteria belonging to the domain Bacteria have been isolated from sediments of hypersaline environments. Most of these bacteria were isolated from athalassohaline environments such as the Dead Sea, inland salt lakes or subterranean waters in oilfields (Oren, 1992; Ollivier et al., 1994; Rainey et al., 1995; Ravot et al., 1997). Few of them have been isolated from thalassohaline environments such as solar salterns (Liaw \& Mah, 1992; Zhilina et al., 1991, 1992; Simankova et al., 1993).

During ecological investigations in solar salterns of the French Mediterranean Coast (Salin-de-Giraud, Camargue, Rhone Delta), we isolated several strains of fermentative halophilic bacteria from the sediments of hypersaline lagoons with total salinities ranging from 13 to $34 \%$. These bacteria co-exist with halophilic, phototrophic and sulfate-reducing bacteria described

The GenBank/EMBL/DDBJ accession number for the $16 \mathrm{~S}$ rRNA sequence of strain SG $3902^{\top}$ is $\mathrm{Y} 18485$ previously by Caumette et al. (1994). Most of the fermentative bacterial isolates belong to the family Halobacteroidaceae. One of these isolates has been described as a new species with the name Haloanaerobacter salinarius, strain SG $3903^{\mathrm{T}}$ (Mouné et al., 1999). Among the other strains isolated, strain SG $3902^{\mathrm{T}}$ is phylogenetically related to the genus Orenia according to $16 \mathrm{~S}$ rDNA similarities. This genus is currently represented by a single species, Orenia marismortui, isolated from the Dead Sea (Oren et al., 1987; Rainey et al., 1995). Isolate $\mathrm{SG} 3902^{\mathrm{T}}$ showed sufficient physiological and genetic differences from the species $O$. marismortui to be considered as a representative of a new member of the genus Orenia. Thus, strain SG $3902^{\mathrm{T}}$ is described here as a new species of the genus, under the name Orenia salinaria sp. nov.

\section{METHODS}

Source of strains. Strain SG $3902^{\mathrm{T}}$ was isolated from the sediment of hypersaline ponds (20-34\% total salinity) in the Salin-de-Giraud salterns (Camargue, France). The sulfiderich black sediment was covered by a thin layer of gypsum; at the highest salinities, a deposit of halite was present. 
Table 1. Substrates fermented by Orenia salinaria strain SG $3902^{\top}$ grown with $10 \%(\mathrm{w} / \mathrm{v}) \mathrm{NaCl}$ under optimal conditions

The following substrates were tested but not utilized: $0 \cdot 1 \%$ starch or glycogen, $6 \mathrm{mM}$ arabinose, xylose, rhamnose, lactose, raffinose, dextrose, arginine or glycerol. +, Substrate utilized; - , substrate not utilized.

\begin{tabular}{|lc|}
\hline Substrate $\mathbf{( 6} \mathbf{~ m M})$ & Utilization \\
\hline Glucose & + \\
Fructose & + \\
Galactose & - \\
Mannose & - \\
Trehalose & + \\
Sucrose & + \\
Maltose & + \\
Cellobiose & + \\
Glucosamine & - \\
$N$-Acetylglucosamine & - \\
Mannitol & + \\
Pyruvate & - \\
Lactate & - \\
Glutamate & - \\
Glycine-betaine & - \\
Trimethylamine & - \\
\hline
\end{tabular}

Media, isolation and culture conditions. The basal synthetic medium used for the growth of strain SG $3902^{\mathrm{T}}$ contained the following (per litre distilled water): $\mathrm{NaCl}, 150 \mathrm{~g}$; $\mathrm{MgCl}_{2} .6 \mathrm{H}_{2} \mathrm{O}, 15 \mathrm{~g} ; \mathrm{KCl}, 3 \mathrm{~g} ; \mathrm{NH}_{4} \mathrm{Cl}, 0.5 \mathrm{~g} ; \mathrm{KH}_{2} \mathrm{PO}_{4}$, $0.35 \mathrm{~g} ; \mathrm{CaCl}_{2} .2 \mathrm{H}_{2} \mathrm{O}, 0 \cdot 05 \mathrm{~g}$; yeast extract, $0 \cdot 1 \mathrm{~g} ; 0 \cdot 1 \%(\mathrm{w} / \mathrm{v})$ resazurin solution, $1 \mathrm{ml}$; trace-element solution SL12 (Overmann et al., 1992), $1 \mathrm{ml}$; selenite/tungstate solution $\left(\mathrm{Na}_{2} \mathrm{SeO}_{3} .5 \mathrm{H}_{2} \mathrm{O}, 6 \mathrm{mg} \mathrm{l}^{-1} ; \mathrm{Na}_{2} \mathrm{WO}_{4} .2 \mathrm{H}_{2} \mathrm{O}, 8 \mathrm{mg} \mathrm{l}^{-1}\right.$; $\left.\mathrm{NaOH}, 0 \cdot 4 \mathrm{~g} \mathrm{l}^{-1}\right), 1 \mathrm{ml} ; \mathrm{NaHCO}_{3}, 2 \mathrm{~g} ; \mathrm{Na}_{2} \mathrm{~S} .9 \mathrm{H}_{2} \mathrm{O}, 0 \cdot 5 \mathrm{~g}$; vitamin V7 solution (Pfennig et al., 1981), $1 \mathrm{ml}$; $\mathrm{pH} 7 \cdot 2-7 \cdot 4$.

The medium was prepared under a gas mixture $\left(\mathrm{N}_{2} / \mathrm{CO}_{2}\right.$, 90:10) according to the method of Pfennig et al. (1981). Prior to inoculation, the medium was supplemented with organic substrates as carbon and energy sources (see Table 1 for substrate utilization).

Pure cultures of strain SG $3902^{\mathrm{T}}$ were obtained by repeated passage through a deep agar dilution series (Pfennig \& Trüper, 1981) in Hungate tubes, with $\mathrm{N}_{2} / \mathrm{CO}_{2}(90: 10)$ in the gas phase and glucose as the organic substrate. The tubes were incubated at $30^{\circ} \mathrm{C}$ in the dark. The purity of the cultures was checked microscopically and by inoculation into different media specific for aerobic bacteria and sulfatereducing bacteria.

Pure strains were grown in liquid cultures under a gas phase $\left(\mathrm{N}_{2} / \mathrm{CO}_{2}, 90: 10\right)$ in $60 \mathrm{ml}$ serum bottles stoppered with butyl rubber stoppers, using the Hungate anaerobic technique. The basal medium was supplemented with glucose $(6 \mathrm{mM})$. After growth at $30^{\circ} \mathrm{C}$, the strains were then stored at $4{ }^{\circ} \mathrm{C}$ in the dark, for periods of 2-4 months.

Microscopy. Microscopic observations and photomicrographs were made with an Olympus OM2 photomicroscope, according to the method of Pfennig \& Wagener (1986).
Flagella were observed by transmission electron microscopy with a JEOL 1200 ES electron microscope after negative staining with $1 \%(\mathrm{v} / \mathrm{v})$ tungstic acid neutralized to $\mathrm{pH} 7 \cdot 2$. The ultrastructure of the cells was studied by transmission electron microscopy after fixation of a cell pellet with osmic acid and ultrathin sectioning of the cells according to the method of Glazer et al. (1971).

Physiological tests. The ability to produce endospores was checked by growth in liquid medium supplemented with $1 \mathrm{mM}$ glucose and $0.18 \mathrm{mM} \mathrm{MnSO}_{4}$ or $0.5 \mathrm{~g}$ yeast extract/soil extract for spore induction, after exposure of the cells to a temperature of $80^{\circ} \mathrm{C}$ for $20 \mathrm{~min}$.

Utilization of carbon sources and electron donors was tested in triplicate in basal liquid medium amended with substrates at the concentrations given in Table 1. Growth tests for utilizable substrates, optimum concentrations of $\mathrm{NaCl}$ and $\mathrm{MgCl}_{2}$, optimum $\mathrm{pH}$, optimum temperature and sulfide tolerance were assessed in completely filled $25 \mathrm{ml}$ screw-cap tubes, as described by Caumette et al. (1988). The glucose fermentation test was carried out in synthetic medium lacking sodium bicarbonate and buffered with $0.4 \mathrm{M}$ Tris/ $\mathrm{HCl}$. The medium was prepared under an $\mathrm{N}_{2}$ gas phase.

For aerobic growth tests, the basal growth medium without sodium bicarbonate and sulfide was buffered with $0 \cdot 4 \mathrm{M}$ Tris/ $\mathrm{HCl}$ and supplemented with glucose as the substrate. Growth was checked in test tubes open to the air and plugged with a cotton-wool stopper. Antibiotic- and antibacterial susceptibility were tested in completely filled screwcap tubes with the growth medium used for maintenance of strains, supplemented with the following substances: anisomycin $\left(40 \mu \mathrm{g} \mathrm{ml}^{-1}\right)$, chloramphenicol $\left(20 \mu \mathrm{g} \mathrm{ml}^{-1}\right)$, tetracycline $\left(40 \mu \mathrm{g} \mathrm{ml}^{-1}\right)$, erythromycin $\left(40 \mu \mathrm{g} \mathrm{ml}^{-1}\right)$, kanamycin $\left(40 \mu \mathrm{g} \mathrm{ml}^{-1}\right)$ and sodium taurocholate $\left(50 \mu \mathrm{g} \mathrm{ml}^{-1}\right)$, according to the method described by Oren (1990). Growth was measured by following the increase in optical density of the cultures at $450 \mathrm{~nm}$ (Spectronic 20; Bausch and Lomb) over a period of $10 \mathrm{~d}$.

The utilization of nitrogen sources (ammonia, nitrate, $\mathrm{N}_{2}$, cysteine) was checked by growth in liquid medium lacking organic or mineral nitrogen compounds, buffered with $\operatorname{MOPS}\left(3 \mathrm{~g} \mathrm{l}^{-1}\right)$ and prepared under an argon gas phase with an adequate nitrogen source. The growth was checked through five consecutive transfers.

Vitamin requirements were determined in $60 \mathrm{ml}$ serum bottles by means of growth tests involving five consecutive transfers in synthetic medium lacking vitamins and yeast extract. Catalase was tested by adding a few drops of $3 \%$ $(\mathrm{v} / \mathrm{v}) \mathrm{H}_{2} \mathrm{O}_{2}$ to a cell pellet on a microscope slide. Oxidase was checked by using the oxidase kit (bioMérieux). The utilization of sulfate, sulfite, thiosulfate or nitrate was tested in Postgate's Medium B (Postgate, 1984), modified by sulfate omission, in $60 \mathrm{ml}$ serum bottles, with glucose as the electron donor. After growth, the utilization of sulfur compounds was determined by means of sulfide production, as revealed by the formation of a black precipitate of $\mathrm{FeS}$ in the liquid culture; nitrate reduction was determined by nitrite production, as revealed by the formation of a red colour following the addition of Griess reagent.

Analytical procedures. The presence of $\mathrm{H}_{2}$ and $\mathrm{CO}_{2}$ among the fermentation products was determined using a Chrompack CP 9001 gas chromatograph equipped with a thermal conductivity detector $\left(135^{\circ} \mathrm{C}\right)$ and a semi-capillary Poraplot Q column (25 m long; $0.53 \mathrm{~mm}$ internal diameter) operated at $35^{\circ} \mathrm{C}$ with either $\mathrm{N}_{2}\left(12 \mathrm{ml} \mathrm{min}^{-1}\right)$ or helium 
$\left(12 \mathrm{ml} \mathrm{min}^{-1}\right)$ as the carrier gas for $\mathrm{H}_{2}$ or $\mathrm{CO}_{2}$ detection, respectively.

A flame-ionization detector $\left(220^{\circ} \mathrm{C}\right)$ was used for alcohol determination, using the same column operated at $150{ }^{\circ} \mathrm{C}$ with helium $\left(12 \mathrm{ml} \mathrm{min}^{-1}\right)$ as the carrier gas.

Organic acids were determined with using HPLC with a Shimadzu LC 6A pump, a PYE Unicam UV detector (at $210 \mathrm{~nm}$ ) and a Rezex organic acid (Phenomenex) column $(300 \mathrm{~mm} \times 7.8 \mathrm{~mm}) ; 5 \mathrm{mM} \mathrm{H}_{2} \mathrm{SO}_{4}$ was used as the solvent at a flow rate of $0.5 \mathrm{ml} \mathrm{min}$. The volume of the injection loop was $20 \mu 1$.

\section{DNA base composition and sequence of the 16S rDNA}

Isolation of genomic DNA. Strain SG $3902^{\mathrm{T}}$ was grown in liquid culture with glucose, lyophilized and stored under 2propanol. Before use, the cells were centrifuged to remove the 2-propanol then resuspended and washed in $0 \cdot 1 \%(\mathrm{w} / \mathrm{v})$ SDS/10 mM Tris-HCl/1 mM EDTA, pH 8.0 (Vargas et al., 1995). Genomic DNA was then prepared as described by Ausubel et al. (1989).

Determination of $\mathrm{G}+\mathrm{C}$ content. The $\mathrm{G}+\mathrm{C}$ content of genomic DNA from SG $3902^{\mathrm{T}}$ was determined by HPLC as decribed by Mesbah et al. (1989), using bacteriophage lambda DNA as the standard.

Amplification of $16 \mathrm{~S}$ rDNA by PCR. A $1.4 \mathrm{~kb}$ fragment of the gene encoding 16S rRNA was amplified by the PCR, using the following primers specified by Amann et al. (1995): sense primer, 5'-AGAGTTTGATCCTGGCTCA-3'; Bacteria, positions 8-26 (Escherichia coli numbering); antisense primer, 5'-ACGGGCGGTGTGTA(G)C-3'; Universal, positions 1406-1392 (E. coli numbering). The PCR reaction mixture contained the following (in $100 \mu \mathrm{l}$ ): $0.5 \mu \mathrm{g}$ genomic DNA; 200 pmol each primer; $50 \mathrm{mM} \mathrm{KCl} ; 10 \mathrm{mM}$ Tris/ $\mathrm{HCl}, \mathrm{pH} 9 \cdot 0 ; 0 \cdot 1 \%(\mathrm{v} / \mathrm{v})$ Triton X-100; $1.25 \mathrm{mM} \mathrm{MgCl}_{2}$; $0.2 \mathrm{mM}$ each dNTP; $5 \%$ (v/v) DMSO; and $2.5 \mathrm{U}$ Taq DNA polymerase (Promega). An initial cycle comprised $3 \mathrm{~min}$ denaturation at $94{ }^{\circ} \mathrm{C}, 2 \mathrm{~min}$ annealing at $50^{\circ} \mathrm{C}$ and $3 \mathrm{~min}$ extension at $72{ }^{\circ} \mathrm{C}$ followed by 34 cycles of 1 min at $94{ }^{\circ} \mathrm{C}$, $2 \mathrm{~min}$ at $50{ }^{\circ} \mathrm{C}$ and $3 \mathrm{~min}$ at $72^{\circ} \mathrm{C}$.

Sequencing of the PCR product. The PCR product was purified after electrophoresis on $1 \%(\mathrm{w} / \mathrm{v})$ agarose gel, using a SephaGlas BandPrep kit (Pharmacia Biotech). The $1.4 \mathrm{~kb}$ PCR product was sequenced directly on an Applied Biosystems Automatic Sequencer (Genome Express), using the PCR and the following two internal primers: 16S-a, 5'ACTCCTACGGGAGGCAGC-3' (E. coli numbering 338$355)$ and $16 \mathrm{~S}-\mathrm{b}^{\prime}, 5^{\prime}$-CGTCAATTCCTTTGAGTTTCA-3' (E. coli numbering 626-906).

Genetic analysis. The $16 \mathrm{~S}$ rRNA/rDNA sequences of 11 species of fermentative, halophilic, anaerobic bacteria were obtained from the EMBL database. The following strains were used (accession nos are in parentheses): Haloanaerobium praevalens DSM 2228 ${ }^{\mathrm{T}}$ (M59123), Halocella cellulolytica DSM 7362 ${ }^{\mathrm{T}}$ (X89072), Halothermothrix orenii OCM 544 ${ }^{\mathrm{T}}$ (L22016), Haloanaerobacter chitinovorans OGC $229^{\mathrm{T}}$ (X89076), Haloanaerobacter lacunaris DSM $6640^{\mathrm{T}}$ (X89075), Haloanaerobacter salinarius DSM $12146^{\mathrm{T}}$ (Y14212), Halobacteroides halobius DSM 5150 (X89074), O. marismortui DSM 5156 ${ }^{\mathrm{T}}$ (X89073), Sporohalobacter lortetii DSM $3070^{\mathrm{T}}$ (M59122), Acetohalobium arabaticum DSM $5501^{\mathrm{T}}$ (X89077) and Megasphaera elsdenii ATCC 17752 (M26493). These sequences were aligned with the sequence of strain SG $3902^{\mathrm{T}}$ by the CLUSTAL W method, using the MEGALIGN program of the DNAStar software package.
The alignment was then modified to remove regions containing unidentified bases or gaps of more than three nucleotides. The subsequent analysis was based on a comparison of approximately 1256 nucleotides.

Analysis of compatible solutes by ${ }^{13} \mathrm{C}-\mathrm{NMR}$ spectroscopy. Strain SG $3902^{\mathrm{T}}$ was grown in 81 batch cultures in the basal medium supplemented with $6 \mathrm{mM}$ glucose and $15 \%(\mathrm{w} / \mathrm{v})$ $\mathrm{NaCl}$. Cultures were incubated at room temperature $\left(25^{\circ} \mathrm{C}\right)$ and continuously sparged with oxygen-free nitrogen to maintain anaerobic conditions. Mid-exponential phase $\left(\mathrm{OD}_{450}=0.3\right)$ cultures were harvested, extracted and analysed by natural abundance spectroscopy according to the methods of Welsh \& Herbert (1994b).

\section{RESULTS}

\section{Enrichment and isolation}

Different types of fermentative bacteria were enriched from the black anoxic sediment below the thin gypsum and halite crust in hypersaline ponds of the Salin-deGiraud (Camargue, France) where the total salinity ranged between 20 and $34 \%$ (w/v). Several strains were purified and isolated by using glucose as the fermentable substrate. One of these, strain SG $3902^{\mathrm{T}}$, was selected for further characterization.

\section{Morphology and fine structure}

The individual cells of strain SG $3902^{\mathrm{T}}$ were long rods, $1 \mu \mathrm{m}$ in width and 6-10 $\mu \mathrm{m}$ in length, in young cultures grown with glucose and $10 \%$ (w/v) $\mathrm{NaCl}$ (Fig. 1a). After the end of the exponential growth phase, they rapidly formed sphaeroplasts and large irregular cells (Fig. 1b). In old cultures, in media appropriate for spore induction, spherical subterminal spores appeared in the cells (Fig. 1c). The cells were motile. Negatively stained cells showed peritrichous flagella (Fig. 2). Electron-microscopic examination of thin sections of strain $\mathrm{SG} 3902^{\mathrm{T}}$ revealed a typical Gramnegative, layered cell envelope (data not shown). Colonies were glossy in surface agar and opaque in deep agar shake tubes. They were white to slightly yellow with entire edges; their diameter ranged from 1 to $2 \mathrm{~mm}$.

\section{Growth and physiology}

Strain SG $3902^{\mathrm{T}}$ grew over a wide salinity range. Growth was observed at $\mathrm{NaCl}$ concentrations between 2 and $30 \%(\mathrm{w} / \mathrm{v}) \mathrm{NaCl}$, with optimal growth at $5-10 \%$. Below $5 \%(\mathrm{w} / \mathrm{v}) \mathrm{NaCl}$ and above $10 \%(\mathrm{w} / \mathrm{v})$ $\mathrm{NaCl}$, the cells were distorted and irregular (Fig. 3). At $2 \%(\mathrm{w} / \mathrm{v}) \mathrm{NaCl}$, the cells were elongated and rapidly formed sphaeroplasts. Above $15 \%$ (w/v) NaCl, very large cells appeared and their number increased with increasing salinity (Fig. 3). At the optimal $\mathrm{NaCl}$ concentration, the optimal temperature for growth of strain SG $3902^{\mathrm{T}}$ was $40-45^{\circ} \mathrm{C}$ and growth occurred at temperatures between 10 and $50^{\circ} \mathrm{C}$. The optimum $\mathrm{pH}$ was 7.2-7.4 and growth was possible between $\mathrm{pH} 5 \cdot 5$ and $\mathrm{pH} 8 \cdot 5$. For optimal growth, strain $\mathrm{SG} 3902^{\mathrm{T}}$ 


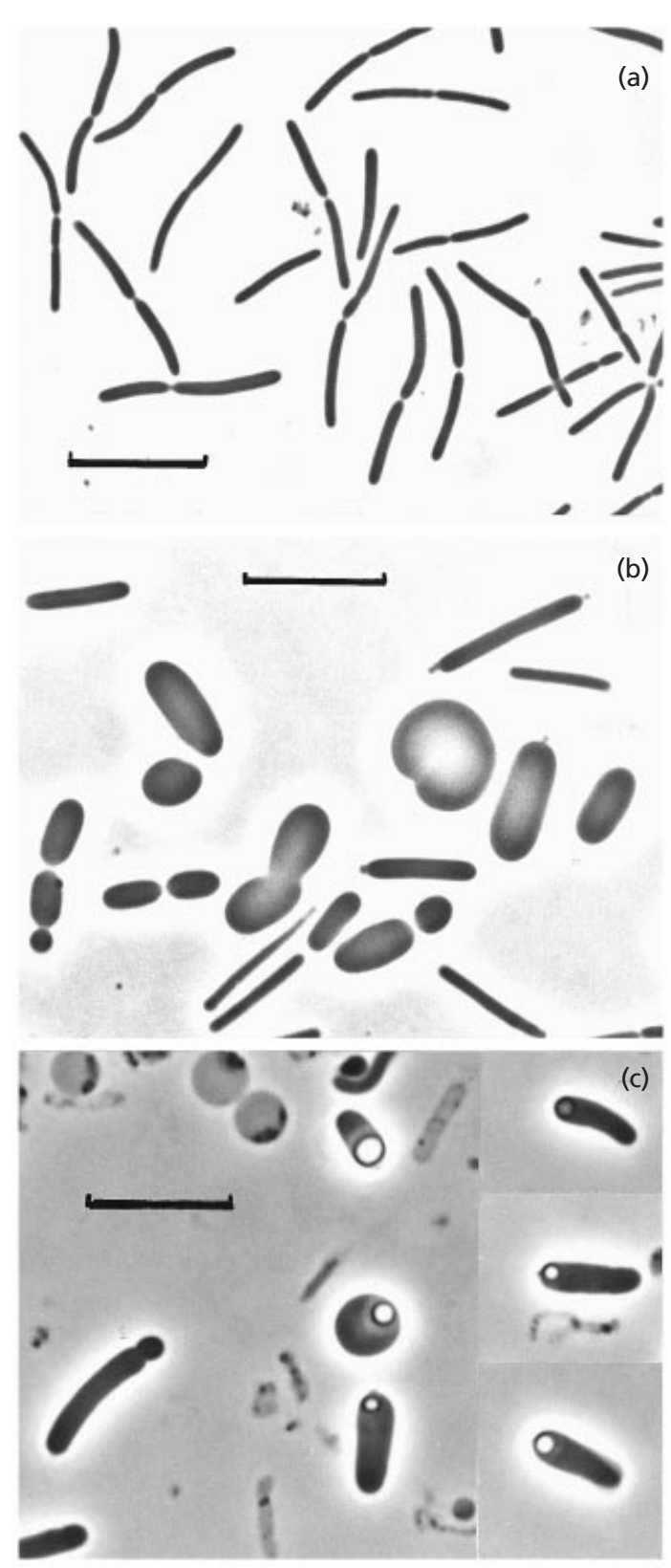

Fig. 1. Microphotographs of O. salinaria strain SG $3902^{\top}$ grown with glucose in the exponential phase of growth (a) and in old cultures with irregular cells (b) or with sporulating cells at different stages of sporulation (c). Bars, $10 \mu \mathrm{m}$.

required a minimum of $1 \mathrm{mM} \mathrm{Mg}{ }^{2+}$. No growth was obtained in the presence of oxygen. Under optimal conditions, the growth rate of strain SG $3902^{\mathrm{T}}$ was $0 \cdot 452 \mathrm{~h}^{-1}$.

The strain showed a high sulfide tolerance, up to $20 \mathrm{mM}$. Neither growth factors nor vitamins were required.

Strain SG $3902^{\mathrm{T}}$ was not capable of dissimilatory reduction of inorganic nitrogen $\left(\mathrm{NO}_{3}^{-}\right)$or sulfur compounds $\left(\mathrm{SO}_{4}^{2-}, \mathrm{SO}_{3}^{2-}, \mathrm{S}_{2} \mathrm{O}_{3}^{2-}\right)$ thus showing that it

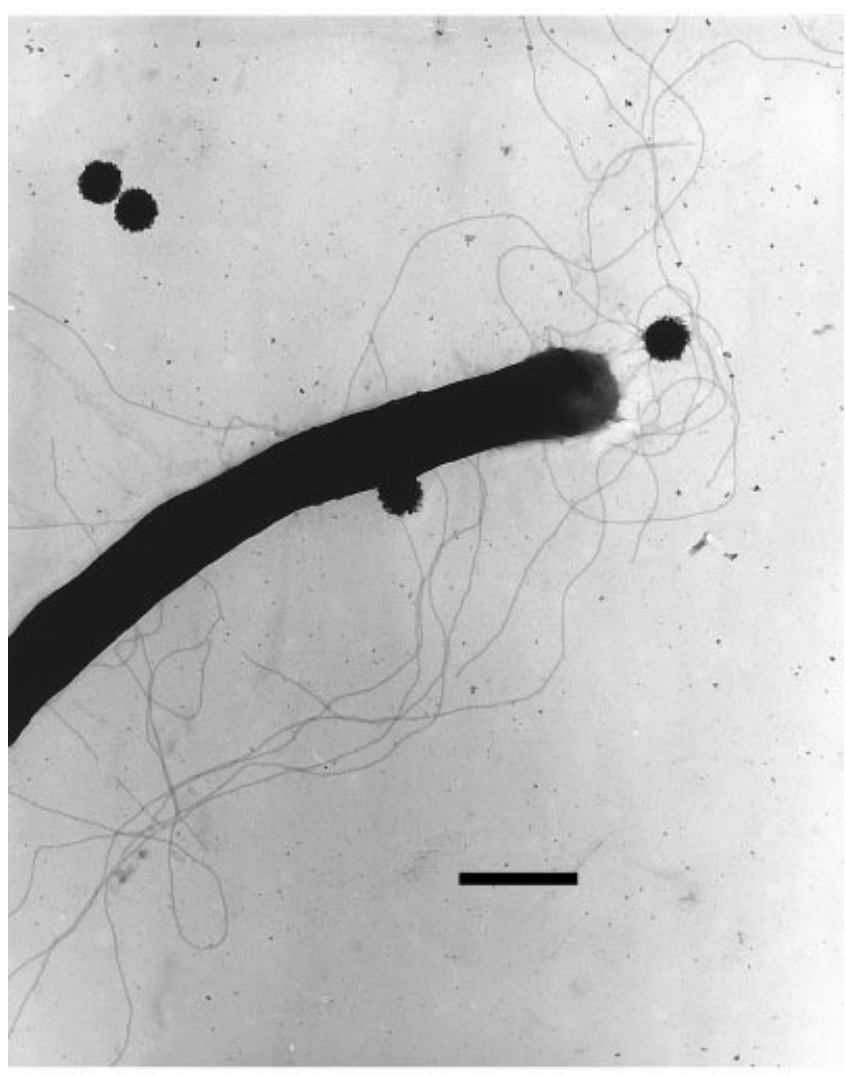

Fig. 2. Electron micrograph of negatively stained cells of $O$. salinaria strain SG $3902^{\top}$ showing peritrichous flagella. Bar, $1 \mu \mathrm{m}$.

has a strictly fermentative metabolism. The strain did not use nitrate or cysteine as a nitrogen source but could use dinitrogen and ammonia when grown through five consecutive transfers in liquid medium lacking other nitrogen sources.

The strain was sensitive to chloramphenicol, erythromycin and tetracycline. However, growth was not inhibited by anisomycin, kanamycin or Na-taurocholate.

Strain SG $3902^{\mathrm{T}}$ used the following fermentable substrates: glucose, fructose, trehalose, sucrose, maltose, cellobiose and mannitol (Table 1). The fermentation products are listed in Table 2. With glucose as the substrate, the major products obtained were ethanol, acetate, formate, lactate, $\mathrm{CO}_{2}$ and $\mathrm{H}_{2}$. Catalase- and oxidase tests were negative.

\section{Genomic characteristics and 16S rDNA gene sequencing}

The $\mathrm{G}+\mathrm{C}$ content of the DNA of strain SG $3902^{\mathrm{T}}$ was $33.7 \mathrm{~mol} \%$.

A partial sequence (1337 nucleotides) of the 16S rRNA gene of strain SG $3902^{\mathrm{T}}$ was determined. The sequence was aligned and a genetic analysis was performed with 

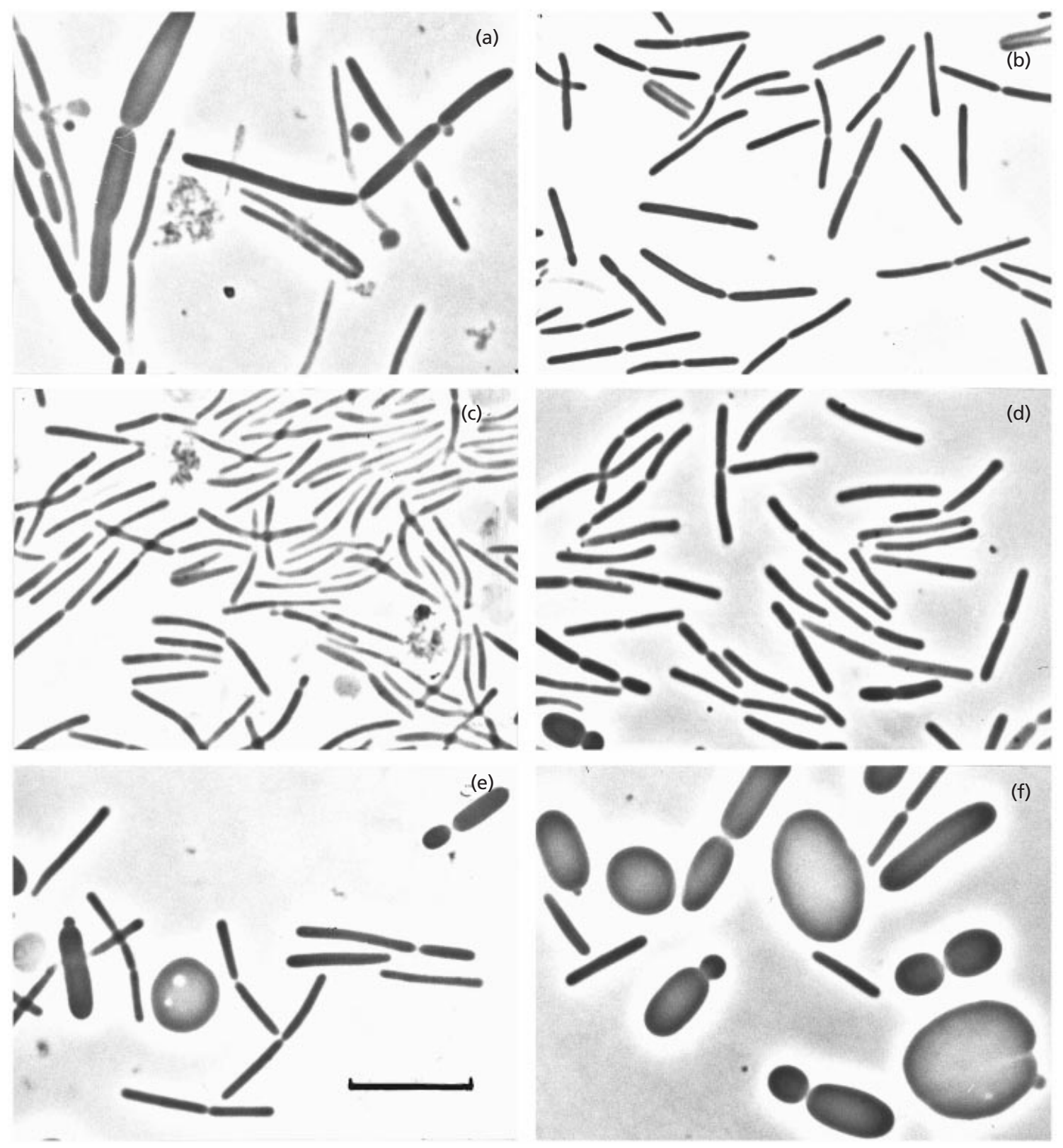

Fig. 3. Photomicrographs of $O$. salinaria strain $S G 3902^{\top}$ grown at different salinities, showing changes in cell morphology: 2 (a), 5 (b), 10 (c), 15 (d), 20 (e) and $25 \% \mathrm{NaCl}$ (f). All of the photomicrographs are at the same magnification. Bar, $10 \mu \mathrm{m}$.

16S rRNA gene sequences of 14 representatives of the closest phyla in the domain Bacteria. A distance matrix based on the Jukes \& Cantor method (1969) showing the percentage similarities and divergences between the different sequences has been constructed. The sequence from $M$. elsdenii was included as the outgroup for rooting the dendrogram. The dendrogram derived from the distance matrix is shown in Fig. 4. Only the type species of the genus Haloanaerobium ( $H$. praevalens, DSM $2228^{\mathrm{T}}$ ) is shown. Strain SG $3902^{\mathrm{T}}$ was most closely related to $O$. marismortui $(95 \cdot 1 \%$ similarity). The next closest species in the neighbouring genus is $H$. halobius ( $90.0 \%$ similarity).

\section{Identification of compatible solutes}

At supra-optimal concentrations, the growth of strain SG $3902^{\mathrm{T}}$ was progressively inhibited resulting both in an increase in the lag phase of growth and a decrease in the growth rate (data not shown). Natural abundance ${ }^{13} \mathrm{C}$ spectra of extracts of strain SG $3902^{\mathrm{T}}$ when grown in media containing $15 \%(\mathrm{w} / \mathrm{v}) \mathrm{NaCl}$ showed strong signals at $55 \cdot 15,67.90$ and $171.56 \mathrm{ppm}$. These signals correspond to authentic glycine-betaine.

Semi-quantitative estimation of the intracellular glycine-betaine content was carried out when the cells were grown at a salinity of $15 \%$. This estimation, 
Table 2. Main characteristics of halophilic fermentative bacteria physiologically or phylogenetically close to Orenia salinaria strain $3902^{\top}$

+ , Positive test result; - , negative test result; ND , not determined.

\begin{tabular}{|c|c|c|c|c|}
\hline Character & $\begin{array}{l}\text { O. salinaria } \\
\text { SG } 3902^{\mathrm{T}}\end{array}$ & $\begin{array}{l}\text { O. marismortui* } \\
\text { DSM } 5156^{\mathrm{T}}\end{array}$ & $\begin{array}{l}\text { S. lortetii } \dagger^{\mathrm{T}} \\
\text { DSM 3070 }\end{array}$ & $\begin{array}{c}\text { Halobacteroides } \\
\text { halobius } \$\end{array}$ \\
\hline $\begin{array}{l}\text { Cell size (width } \times \text { length, } \\
\mu \mathrm{m})\end{array}$ & $1 \times 6-10$ & $0 \cdot 6 \times 3-13$ & $0.5 \times 2.5-10$ & $0.5 \times 10-20$ \\
\hline Morphology & Rod & Rod & Rod & Long rod \\
\hline Spore formation & - & + & + & - \\
\hline Gas vacuole & - & $\mathrm{ND}$ & + & - \\
\hline $\mathrm{NaCl}$ range $(\%)$ & $2-25$ & $3-18$ & $4-15$ & $8-30$ \\
\hline $\mathrm{NaCl}$ optimum (\%) & $5-10$ & $3-12$ & $8-9$ & $9-15$ \\
\hline Temp. range $\left({ }^{\circ} \mathrm{C}\right)$ & $10-50$ & $25-50$ & $25-52$ & $30-47$ \\
\hline Temp. optimum $\left({ }^{\circ} \mathrm{C}\right)$ & $40-45$ & $36-45$ & $37-45$ & $37-42$ \\
\hline $\mathrm{pH}$ range & $5 \cdot 5-8 \cdot 5$ & ND & ND & ND \\
\hline pH optimum & $7 \cdot 2-7 \cdot 4$ & $\mathrm{ND}$ & ND & $\mathrm{ND}$ \\
\hline $\begin{array}{l}\mathrm{G}+\mathrm{C} \text { content of DNA } \\
(\mathrm{mol} \%)\end{array}$ & $33 \cdot 7$ (HPLC) & $29 \cdot 6(\mathrm{mp})$ & $31 \cdot 5(\mathrm{mp})$ & $30 \cdot 7(\mathrm{mp})$ \\
\hline $\begin{array}{l}\text { Utilization of } \mathrm{N}_{2} \\
\text { Substrates fermented: }\end{array}$ & + & $\mathrm{ND}$ & $\mathrm{ND}$ & $\mathrm{ND}$ \\
\hline Galactose & - & - & - & + \\
\hline Sucrose & + & + & $\mathrm{ND}$ & + \\
\hline Mannose & - & + & - & + \\
\hline Glutamate & - & - & + & ND \\
\hline Glycogen & - & + & ND & ND \\
\hline Starch & - & + & + & + \\
\hline Amino acids & - & - & + & - \\
\hline Pyruvate & - & - & ND & + \\
\hline $\begin{array}{l}\text { Glucose fermentation } \\
\text { products }\end{array}$ & $\begin{array}{l}\text { Lactate, formate, } \\
\text { acetate, ethanol, } \mathrm{CO}_{2} \text {, } \\
\mathrm{H}_{2}\end{array}$ & $\begin{array}{l}\text { Formate, acetate, } \\
\text { ethanol, } \mathrm{CO}_{2}, \mathrm{H}_{2}\end{array}$ & $\begin{array}{l}\text { Acetate, propionate, } \\
\text { butyrate, isobutyrate, } \\
\text { isovalerate, } \mathrm{H}_{2}\end{array}$ & $\begin{array}{l}\text { Acetate, ethanol, } \mathrm{CO}_{2}, \\
\mathrm{H}_{2}\end{array}$ \\
\hline
\end{tabular}

* From Oren et al. (1987).

$\dagger$ From Oren (1983).

$\$$ From Oren et al. (1984).

based on peak height of the NMR spectra (with acetate as the internal standard), yielded a value of $1 \cdot 9-2 \cdot 2 \mu \mathrm{mol}$ (mg protein $)^{-1}$.

\section{DISCUSSION}

Strain SG $3902^{\mathrm{T}}$ is a Gram-negative, rod-shaped, carbohydrate-fermenting, halophilic, obligate anaerobe that grows optimally at $\mathrm{NaCl}$ concentrations of $50-100 \mathrm{~g} \mathrm{l}^{-1}$. These characteristics are consistent with the assignment of strain SG $3902^{\mathrm{T}}$ to the family Halobacteroidaceae (Rainey et al., 1995). The genetic relatedness study based on comparison of $16 \mathrm{~S}$ rDNA sequences showed that strain SG $3902^{\mathrm{T}}$ is a member of this family. In the Halobacteroidaceae cluster, strain SG $3902^{\mathrm{T}}$ is included with the group composed of the genera Orenia and Halobacteroides (see Fig. 4). In this cluster, strain SG $3902^{\mathrm{T}}$ is most closely related to the species $O$. marismortui $(95 \cdot 1 \%$ sequence identity). On the basis of this phylogenetic relatedness (only $5 \%$ difference), our strain SG $3902^{\mathrm{T}}$ should be considered as a new representative of the genus Orenia. However, with respect to its DNA base composition (Table 2), Orenia strain SG $3902^{\mathrm{T}}(\mathrm{G}+\mathrm{C}$ content $33.7 \mathrm{~mol} \%)$ is closer to S. lortetii $(\mathrm{G}+\mathrm{C}$ content $31.5 \mathrm{~mol} \%)$ than to O. marismortui $(\mathrm{G}+\mathrm{C}$ content $29.6 \mathrm{~mol} \%)$ or H. halobius $(\mathrm{G}+\mathrm{C}$ content $30 \cdot 7 \mathrm{~mol} \%)$.

Like $O$. marismortui and S. lortetii, Orenia strain SG $3902^{\mathrm{T}}$ is capable of sporulation. However, the spore formation in this strain was not evident when the strain was grown in the defined medium. Spores could be produced in high numbers only after growth in media supplemented with $\mathrm{MnSO}_{4}$ or yeast/soil extract.

Orenia strain SG $3902^{\mathrm{T}}$ uses a rather limited number of carbohydrates compared to its relatives (Table 2). In particular, it is unable to use polysaccharides (glycogen, starch), in contrast to $O$. marismortui, $H$. halobius and $S$. lortetii, all of which are able to metabolize such molecules. Physiologically, S. lortetii is rather different, having a capacity to degrade amino acids and to use a different metabolic pathway for 


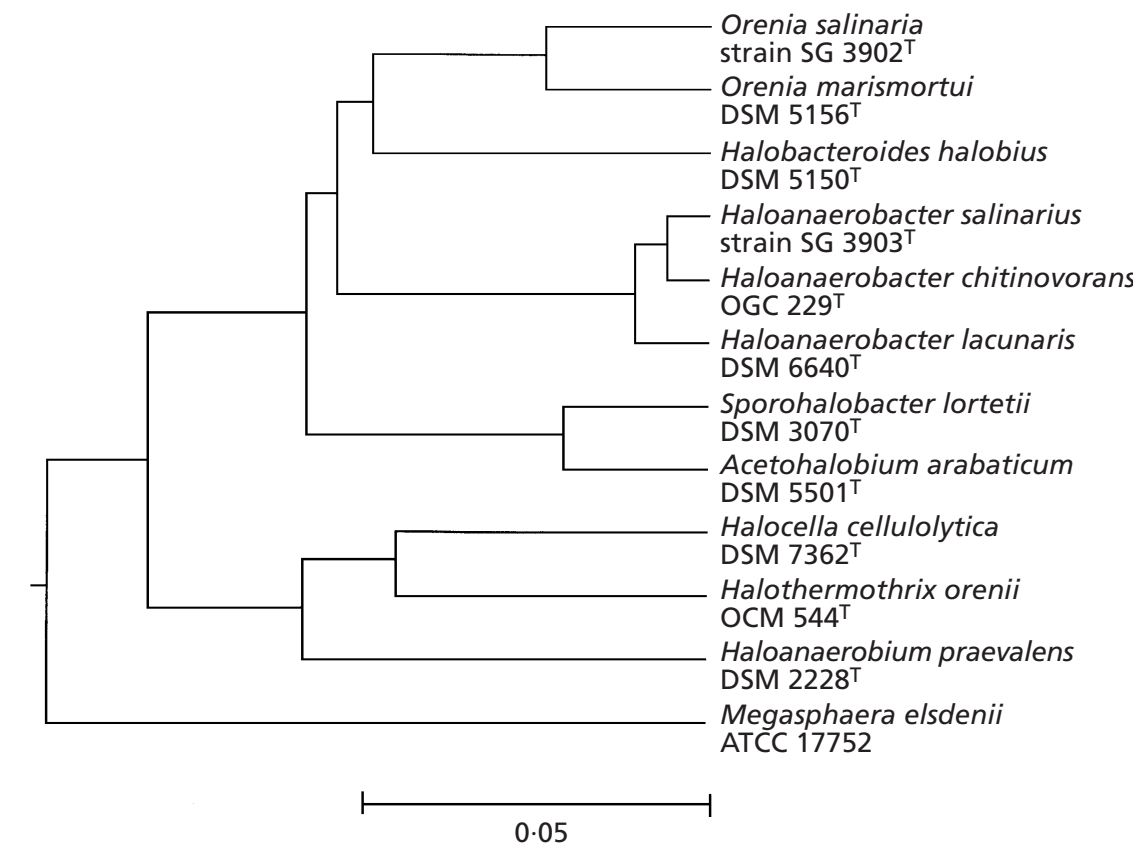

Fig. 4. Phylogenetic tree based on similarities of 165 DNA sequences of $O$. salinaria strain SG $3902^{\top}$ and its relatives. The bar represents the distance $\left(K_{\text {nuc }}\right)$ corresponding to 5 nucleotide differences per 100 nucleotides. glucose fermentation (Table 2). According to the products obtained from glucose fermentation, both Orenia strains use the mixed acid pathway, whereas $S$. lortetii probably has a fermentative pathway similar to that for butyric acid fermentation.

An interesting property of Orenia strain SG $3902^{\mathrm{T}}$ was the capacity to use $\mathrm{N}_{2}$ as the sole nitrogen source, thus suggesting the presence of a nitrogenase activity in this strain. This property has not been demonstrated in the Haloanaerobiales or in O. marismortui.

Orenia strain SG $3902^{\mathrm{T}}$ was isolated from one of the most hypersaline ponds in the Salin-de-Giraud; the water salinity ranged between 20 and $34 \%$. It was isolated from the sediment immediately underlying a photosynthetic microbial mat composed of cyanobacteria and purple bacteria. When the salinity increases above $30 \%$, the microbial mats start to decompose and the coloured layers due to the presence of the photosynthetic micro-organisms are no longer visible. However, most of these bacteria are still present, coexisting with the fermentative bacteria.

The salinity range of Orenia strain SG $3902^{\mathrm{T}}$ suggests adaptation to this environment, although its optimum salinity $(5-10 \%, \mathrm{w} / \mathrm{v}, \mathrm{NaCl})$ was lower than the usual salinity range in the water. The strain is able to adapt to such salinities (up to $25 \%, w / v, \mathrm{NaCl}$ ) and subsequent osmotic pressures by the synthesis or uptake of osmotically compatible solutes, principally glycine-betaine. The strain was grown with yeast extract in the culture medium. Since yeast extract contains significant amounts of glycine-betaine (Dulaney et al., 1968), Orenia strain SG $3902^{\mathrm{T}}$ may possess a functional glycine-betaine-uptake system. Whilst osmotically regulated glycine-betaine transport systems are widespread amongst halotolerant and many halophilic eubacteria (Galinski \& Trüper, 1994; Welsh \& Herbert, 1994a, b), they have not been reported previously for anaerobic halophiles (Galinski, 1995). Recently, Oren (1999) reported that osmoregulatory processes in the Haloanaerobiales are mainly mediated via mineral salt accumulation and that compatible solutes were never detected in the cells of the described species. As stated by Oren (1999), the synthesis of compatible solutes like glycine-betaine is energetically expensive and difficult for a fermentative bacterium that obtains only a small amount of energy from its substrate. Thus, the accumulation of mineral salts in the cells is a 'cheaper' solution for balancing the external salinity. However, Orenia strain SG $3902^{\mathrm{T}}$ is the first strain of the Haloanaerobiales that is known to accumulate glycine-betaine in the cells in rather large amounts [up to $2 \cdot 2 \mu \mathrm{mol}(\mathrm{mg} \text { protein })^{-1}$ ], probably via an uptake metabolism.

From an ecological standpoint, the ability to accumulate compatible solutes such as glycine-betaine is advantageous since it is energetically more favourable than synthesis. In hypersaline environments such as the Salin-de-Giraud salterns, a diverse range of oxygenic and anoxygenic phototrophs synthesize glycinebetaine as a compatible solute (Caumette, 1993; Caumette et al., 1994) and hence it is likely to be readily available, in the sediment, to fermentative bacteria such as strain $3902^{\mathrm{T}}$.

Thus, according to all the genetic and physiological characteristics discussed above, and particularly in view of the $16 \mathrm{~S}$ rDNA differences relative to the existing species, strain SG $3902^{\mathrm{T}}$ can be considered as a representative of a new species of the genus Orenia, under the name Orenia salinaria sp. nov. 


\section{Description of Orenia salinaria sp. nov.}

Orenia salinaria (sa.li.na'ria. L. adj. salinaria pertaining to salinae salterns, salt-works).

Cells are Gram-negative, colourless, sporulating rods, motile by peritrichous flagella. The cells are long $(1 \mu \mathrm{m}$ wide $\times 6-10 \mu \mathrm{m}$ long) in young cultures; large degenerate cells and sphaeroplasts are common in old cultures, as are spherical subterminal spores. Surface colonies are circular, translucid, glossy and are white to slightly yellow with entire edges. Colony diameters range from 1 to $2 \mathrm{~mm}$. Obligately halophilic. Growth occurs at $\mathrm{NaCl}$ concentrations between 2 and $25 \%$ $(\mathrm{w} / \mathrm{v}) \mathrm{NaCl}$; optimal growth is at $5-10 \%$. The cells accumulate glycine-betaine as the compatible solute. The temperature range for growth is $10-50{ }^{\circ} \mathrm{C}$, with an optimum at $40-45^{\circ} \mathrm{C}$. The $\mathrm{pH}$ range is $5 \cdot 5-8 \cdot 5$, with an optimum at $\mathrm{pH} 7 \cdot 2-7 \cdot 4$. Cells are susceptible to chloramphenicol, erythromycin and tetracycline; they are resistant to anisomycin, kanamycin and $\mathrm{Na}$ taurocholate. Obligately anaerobic fermentative; catalase- and oxidase-negative. Glucose, fructose, trehalose, sucrose, maltose, cellobiose and mannitol are fermented. The major products of glucose fermentation are ethanol, formate, acetate, lactate, $\mathrm{CO}_{2}$ and $\mathrm{H}_{2}$. Growth occurs with $\mathrm{N}_{2}$ as the sole nitrogen source. The $\mathrm{G}+\mathrm{C}$ content of the DNA is $33.7 \mathrm{~mol} \%$ (HPLC). The habitat is anoxic organic sediment from solar salterns. The type strain is strain SG $3902^{\mathrm{T}}$ $\left(=\right.$ ATCC $\left.700911^{\mathrm{T}}\right)$, isolated from salt ponds in the salterns of Salin-de-Giraud (Camargue, France). The EMBL 16S rRNA gene sequence accession number is Y18485.

\section{ACKNOWLEDGEMENTS}

This work was partly supported by a grant from the French Ministry of Education and Research (MESR ACC-SV7) and a grant from the Regional Council of Aquitaine. The authors thank the Compagnie des Salins du Midi for its authorization to sample and work in the salterns of Salin-deGiraud. R. Baulaigue is acknowledged for her technical assistance.

\section{REFERENCES}

Amann, R. I., Ludwig, W. \& Schleifer, K. H. (1995). Phylogenetic identification and in situ detection of individual microbial cells without cultivation. Microbiol Rev 59, 143-169.

Ausubel, F. M., Brent, R., Kingston, R. E., Moore, D. D., Seidman, J. G., Smith, J. A. \& Struhl, K. (1989). Short Protocols in Molecular Biology. New York: Wiley.

Caumette, P. (1993). Ecology and physiology of phototrophic bacteria and sulfate-reducing bacteria in marine salterns. Experientia 49, 473-481.

Caumette, P., Baulaigue, R. \& Matheron, R. (1988). Characterization of Chromatium salexigens sp. nov., a halophilic Chromatiaceae isolated from Mediterranean Salinas. Syst Appl Microbiol 10, 284-292.

Caumette, P., Matheron, R., Raymond, N. \& Relexans, J.-C. (1994). Microbial mats in the hypersaline ponds of Medi- terranean Salterns (Salin-de-Giraud, France). FEMS Microbiol Ecol 13, 273-286.

Dulaney, E. L., Dulaney, D. D. \& Ricks, E. L. (1968). Factors in yeast extract which relieve growth inhibition of bacteria in defined medium of high osmolarity. Dev Ind Microbiol 9, 260-269.

Galinski, E. A. (1995). Osmoadaptation in bacteria. $A d v$ Microb Physiol 37, 273-328.

Galinski, E. A. \& Trüper, H. G. (1994). Microbial behaviour in salt-stressed ecosystems. FEMS Microbiol Rev 15, 95-108.

Glazer, A. N., Cohen-Bazire, G. \& Stanier, R. Y. (1971). Characterization of phycoerythrin from a Cryptomonas species. Arch Microbiol 80, 1-8.

Jukes, T. H. \& Cantor, C. R. (1969). Evolution of protein molecules. In Mammalian Protein Metabolism, vol. 3, pp. 21-132. Edited by H. N. Munro. New York: Academic Press.

Liaw, H. J. \& Mah, R. A. (1992). Isolation and characterization of Haloanaerobacter chitinovorans gen. nov., sp. nov., a halophilic, anaerobic, chitinolytic bacterium from a solar saltern. Appl Environ Microbiol 58, 260-266.

Meshbah, M., Premachandran, U. \& Whitman, W. B. (1989). Precise measurement of the $\mathrm{G}+\mathrm{C}$ content of deoxyribonucleic acid by high-performance liquid chromatography. Int J Syst Bacteriol 39, 159-167.

Mouné, S., Manac'h, N., Hirschler, A., Caumette, P., Willison, J. C. \& Matheron, R. (1999). Haloanaerobacter salinarius sp. nov., a novel halophilic fermentative bacterium that reduces glycinebetaine to trimethylamine with hydrogen or serine as electron donors; emendation of the genus Haloanaerobacter. Int J Syst Bacteriol 49, 103-112.

Ollivier, B., Caumette, P., Garcia, J.-L. \& Mah, R. A. (1994). Anaerobic bacteria from hypersaline environments. Microbiol Rev 58, 27-38.

Oren, A. (1983). Clostridium lortetii sp. nov., a halophilic obligatory anaerobic bacterium producing endospores with attached gas vacuoles. Arch Microbiol 136, 42-48.

Oren, A. (1990). The use of protein synthesis inhibitors in the estimation of the contribution of halophilic archaebacteria to bacterial activity in hypersaline environments. FEMS Microbiol Ecol 73, 187-192.

Oren, A. (1992). The genera Haloanaerobium, Halobacteroides, and Sporohalobacter. In The Prokaryotes, 2nd edn, vol. 2, pp. 1893-1900. Edited by A. Balows, H. G. Trüper, M. Dworkin, W. Harder \& K. H. Schleifer. New York: Springer.

Oren, A. (1999). Bioenergetic aspects of halophilism. Microbiol Mol Biol Rev 63, 334-348.

Oren, A., Weisburg, W. G., Kessel, M. \& Woese, C. R. (1984). Halobacteroides halobius gen. nov., sp. nov., a moderately halophilic anaerobic bacterium from the bottom sediments of the Dead Sea. Syst Appl Microbiol 5, 58-69.

Oren, A., Pohla, H. \& Stackebrandt, E. (1987). Transfer of Clostridium lortetii to a new genus, Sporohalobacter gen. nov. as Sporohalobacter lortetii comb. nov., and description of Sporohalobacter marismortui sp. nov. Syst Appl Microbiol 9, 239-246.

Overmann, J., Fischer, U. \& Pfennig, N. (1992). A new purple sulfur bacterium from saline littoral sediments, Thiorhodovibrio winogradskyi gen. nov. and sp. nov. Arch Microbiol 157, 329-335.

Pfennig, N. \& Trüper, H. G. (1981). Isolation of members of the families Chromatiaceae and Chlorobiaceae. In The Prokaryotes, vol. 1, pp. 279-289. Edited by M. P. Starr, H. Stolp, 
H. G. Trüper, A. Balows \& H. G. Schlegel. Berlin \& Heidelberg: Springer.

Pfennig, N. \& Wagener, S. (1986). An improved method of preparing wet mounts for photomicrographs of microorganisms. J Microbiol Methods 4, 303-306.

Pfennig, N., Widdel, F. \& Trüper, H. G. (1981). The dissimilatory sulfate-reducing bacteria. In The Prokaryotes, vol. 1, pp. 926-940. Edited by M. P. Starr, H. Stolp, H. G. Trüper, A. Balows \& H. G. Schlegel. Berlin \& Heidelberg: Springer.

Postgate, J. R. (1984). The Sulphate-reducing Bacteria. Cambridge: Cambridge University Press.

Rainey, F. A., Zhilina, T. N., Bulygina, E. S., Stackebrandt, E., Tourova, T. P. \& Zavarzin, G. A. (1995). The taxonomic status of the fermentative halophilic anaerobic bacteria: description of Haloanaerobiales ord. nov., Halobacteroidaceae fam. nov., Orenia gen. nov. and further taxonomic rearrangements of the genus and species level. Anaerobe 1, 185-199.

Ravot, G., Magot, M., Ollivier, B., Patel, B. K. C., Ageron, E., Grimont, P. A. D., Thomas, P. \& Garcia, J.-L. (1997). Haloanaerobium congolense sp. nov., an anaerobic, moderately halophilic, thiosulfate- and sulfur-reducing bacterium from an African oil field. FEMS Microbiol Lett 147, 81-88.

Simankova, M. V., Chernych, N. A., Osipov, G. A. \& Zavarzin, G. A. (1993). Halocella cellulolytica gen. nov., sp. nov., a new obligately anaerobic, halophilic, cellulolytic bacterium. Syst Appl Microbiol 16, 385-389.

Vargas, C., Fernandez-Castillo, R., Canovas, D., Ventosa, A. \& Nieto, J. J. (1995). Isolation of cryptic plasmids from moderately halophilic eubacteria of the genus Halomonas. Characterization of a small plasmid from $H$. elongata and its use for shuttle vector construction. Mol Gen Genet 246, 411-418.

Welsh, D. T. \& Herbert, R. A. (1994a). Osmoadaptation of Thiocapsa roseopersicina $\mathrm{OP}-1$ in batch and continuous culture: accumulation of $\mathrm{K}^{+}$and sucrose in response to osmotic stress. FEMS Microbiol Ecol 13, 151-158.

Welsh, D. T. \& Herbert, R. A. (1994b). Identification of organic solutes accumulated in purple and green sulfur bacteria during osmotic stress using natural abundance ${ }^{13} \mathrm{C}$ nuclear magnetic spectroscopy. FEMS Microbiol Ecol 13, 745-750.

Zhilina, T. N., Miroshnikova, L. V., Osipov, G. A. \& Zavarzin, G. A. (1991). Halobacteroides lacunaris sp. nov., new saccharolytic, anaerobic, extremely halophilic organism from the lagoon-like hypersaline Lake Chokrak. Microbiology (English translation of Mikrobiologiya) 60, 495-503.

Zhilina, T. N., Zavarzin, G. A., Bulygina, E. S., Kevbrin, V. V., Osipov, G. A. \& Chumakov, K. M. (1992). Ecology, physiology and taxonomy studies on a new taxon of Haloanaerobiaceae, Haloincola saccharolytica gen. nov., sp. nov. Syst Appl Microbiol 15, 275-284. 